Prosiding Seminar Nasional Teknologi Informasi dan Kedirgantaraan : Transformasi Teknologi untuk Mendukung Ketahanan Nasional, Yogyakarta, 13 Desember 2018

SENATIK 2018, Vol. IV, ISBN 978-602-52742-0-6

DOI: http://dx.doi.org/10.28989/senatik.v4i0.220

\title{
THE ERGONOMIC ANALYSIS OF THE AIRLINE PASSENGERS MESSAGE SERVICE TO IMPROVE THE FLIGHT SAFETY Eko Poerwanto ${ }^{1}$, Haruno Sajati $^{2)}$, Ragil Andaruwati ${ }^{2)}$ \\ ${ }^{1}$ Program Studi Teknik Industri \\ ${ }^{2}$ Program Studi Teknik Informatika \\ Sekolah Tinggi Teknologi Adisutjipto \\ Jl. Janti Blok-R Lanud Adisutjipto, Yogyakarta 55198 \\ Email: 1'ekoevtas@gmail.com
}

\begin{abstract}
A message/complaint service is a very strategic facility for all stakeholders of an industrial organization. The ergonomic message/ complaint service in the aviation industry is an ergonomics approach based on a standard service system provided by an airline which iseasily accessed/ used and the given response is according to the airline passenger expectations. This research was started by observing the message service/ complaint facilities in the aviation industry (airline) and then the function was analyzed and the improvement to service system facilities was proposed so that it was convenient for the users. The results of the study concluded that there were already message / complaint service facilities in the aviation industry (Airline) but they are not ergonomic and optimal to improve the flight safety, so it is necessary to integrate the message / complaint service system with the safety services to empower the State Safety Program (SSP) according to recommendations of International Civil Aviation Organization (ICAO) annex 13, aircraft accidents and incident investigations to improve the flight safety performance.
\end{abstract}

Keywords: Message/ Complaint Services, Ergonomics, Flight Safety.

\section{Pendahuluan}

Layanan Pesan merupakan fasilitas yang sangat strategis bagi seluruh stakeholder dalam melakukan operasional suatu organisasi Industri, karena layanan pesan merupakan bentuk komunikasi bagi seluruh stakeholder dalam suatu organisasi Industri. Keselamatan penerbangan dapat tercipta hanya oleh kerjasama yang baik dari seluruh stakeholder dalam penerbangan. Artinya, setiap stakeholder penerbangan memiliki tanggung jawab dan kontribusi terhadap terciptanya keselamatan penerbangan. Sebagai bagian dari suatu sistem, apabila salah satu institusi tidak memainkan peranannya dengan baik, walaupun institusiinstitusi yang lain telah menunjukkan kinerja yang baik, tetap saja keselamatan penerbangan akan sulit terwujud. Selain permasalahan keselamatan pada penerbangan di Indonesia, permasalahan yang lain adalah tentang pelayanan penerbangan, misalkan berkaitan dengan delay atau kinerja airline yaitu on time performance yang saat ini sering dipermasalahkan konsumen. Hal ini menunjukkan adanya banyak permasalahan di industri penerbangan di Indonesia yang cukup kompleks dan sistemik. Oleh karena itu, penting sekali melakukan analisis ergonomi layanan pesan penumpang airline untuk meningkatkan keselamatan penerbangan di Indonesia.

Layanan Pesan/Keluhan yang Ergonomi adalah suatu pendekatan ergonomi berbasis pada sistem layanan standar yang disediakan oleh penyedia jasa angkutan udara (airline) dan mudah diakses/digunakan serta respon yang diberikan sesuai harapan penumpang airline.Sistem layanan tersebut untuk meningkatkan performanya maka pesan harus dipisahkan menjadi pesan layanan dan pesan keselamatan dalam penerbangan yang prosesnya melewati mekanisme pendistrbusian pesan dalam suatu organisasi dalam suatu sistem kerja. 
Secara konseptual layanan pesan yang ergonomi merupakan suatu pendekatan sosioteknik yang diterapkan dalam perancangan sistem kerja secara keseluruhan. Penelitian layanan pesan yang ergonomi pada suatu airline melibatkan seperti teknologi informasi, personil, desain standar pesan serta bagaimana interaksi didalamnya. Jadi layanan pesan yang ergonomi diaplikasikan untuk mengoptimasi sebuah sistem kerja secara keseluruhan.

Hasil Safety Audit yang dilakukan oleh ICAO dengan programnya Universal Safety Oversight Audit Programme (USOAP) /Comprehensive System Approach beserta Continuous Monitoring Approach melalui sistem pendekatan penggunaan Annex yang terkait meliputi :Legislation, Organization, Licensing, Operations, Airworthiness , Air Navigationc Services, Accident Investigation dan Aerodromes, menunjukkan bahwa Indonesia sudah berada di atas rata-rata (Global average) dan Singapore merupakan yang terbaik di ASEAN. Gambaran hasil Safety Audit yang dilakukan oleh ICAO dengan programnya Universal Safety Oversight Audit Programme (USOAP) /Comprehensive System Approach beserta Continuous Monitoring Approach adalah sebagai berikut :

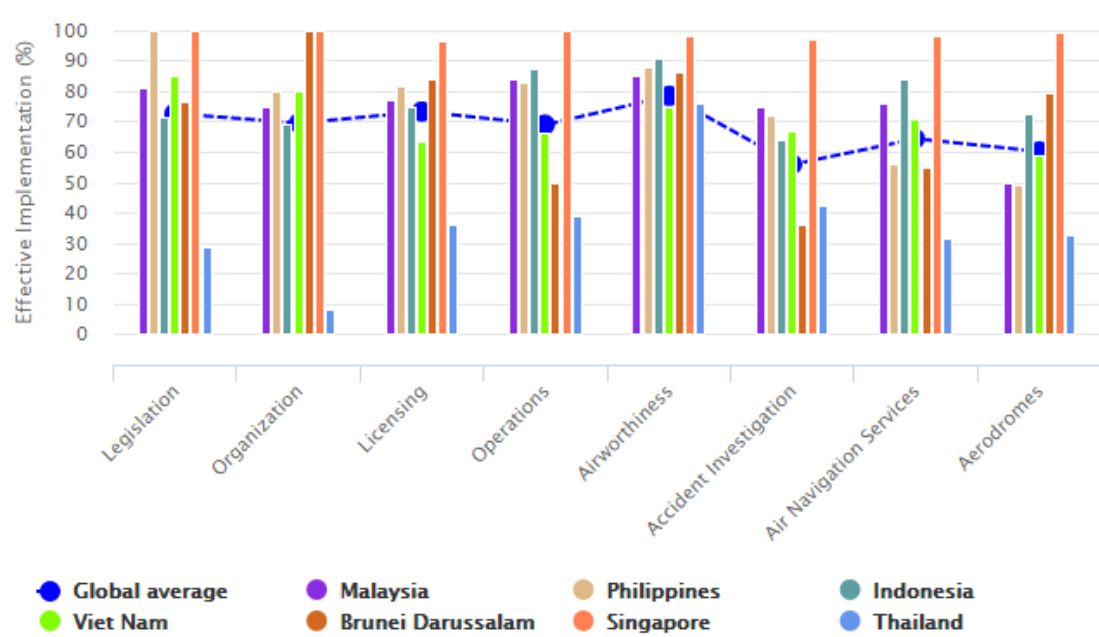

Gambar 1. Nilai Safety Audit ICAO Negara ASEAN

Sumber : (https://www.icao.int/safety/Pages/USOAP-Results.aspx) diakses 7 November 2018

Nilai audit USOAP yang baik adalah yang memenuhi syarat ICAO yaitu yang berada di antara rentang nilai terendah yaitu batas nilai rata-rata global (Global average) dengan nilai tertinggi yaitu yang mencapai batas teratas (100\%). Posisi Industri Penerbangan (Airline) di Indonesia sudah sebagian indikator berada diatas global average, hal ini merupakan usaha keras seluruh pihak pemangku kepentingan di Industri Penerbangan untuk meningkatkan kinerjanya sehingga meningkatkan tingkat safety dengan meningkatkan performa pesan layanan dan pesan keselamatan terutama dari stakeholderairline. Walaupun penilaian tersebut menunjukkan prestasi yang cukup baik mengapa masih terjadi kecelakaan dalam penerbangan, hal ini karena faktornya sangat banyak salah satunya adalah manusia dan sistem layanan informasi yang perlu dibenahi.

Layanan keluhan dalam Industri Penerbangan dapat bersifat dua hal yaitu Pesan Layanan dan Pesan Keselamatan, sehingga sesuai dengan PM 185 Tahun 2015, Bab VIII tentang Pengawasan dan Penilaian, pasal 66 bahwa "Badan usaha angkutan udara wajib menyampaikan laporan keluhan pengguna jasa angkutan udara dan tindak penanganan keluhan kepada Direktur Jenderal paling lambat 10 (sepuluh) bulan berikutnya". Hal ini menunjukkan bahwa pada Industri Penerbangan setiap masukan/data/informasi dari seluruh stakeholder akan diolah dan dijadikan acuan dalam penilaian performa kerja dan performa 
dalam meningkatkan keselamatan penerbangan. Sesuai dengan visi dan misi Penerbangan Sipil bahwa keselamatan penerbangan adalah yang paling utama.

Sesuai dengan pasal 69 regulasi tersebut, bahwa "Direktur Jenderal mengumumkan hasil penilaian pelaksanaan standar pelayanan badan usaha angkutan udara niaga berjadwal melalui media publikasi setiap 6 (enam) bulan". Hal ini dilakukan sebagai bagian dari "Promosi", bahwa budaya akan muncul dalam diri manusia jika setiap kegiatan yang ada diapresiasikan secara positif.

Layanan Pesan Penumpang Airline secara umum dapat dilakukan dengan menggunakan media online dan offline, seperti, Customer Service, Telepon (Call Center) dan Short Message Service (SMS), menggunakan situs resmi masing-masing Airline serta dapat langsung melalui Short Message Service (SMS)ke 0811999920 yang disediakan oleh Dirjen Perhubungan Udara, Kementerian Perhubungan. Layanan Pesan yang dilaporkan melalui Dirjen Perhubungan Udara datanya akan masuk ke State Safety Programme (SSP), yang secara umum sistem pelaporan dalam SSP ini digambarkan dalam diagram konteks sebagai berikut:

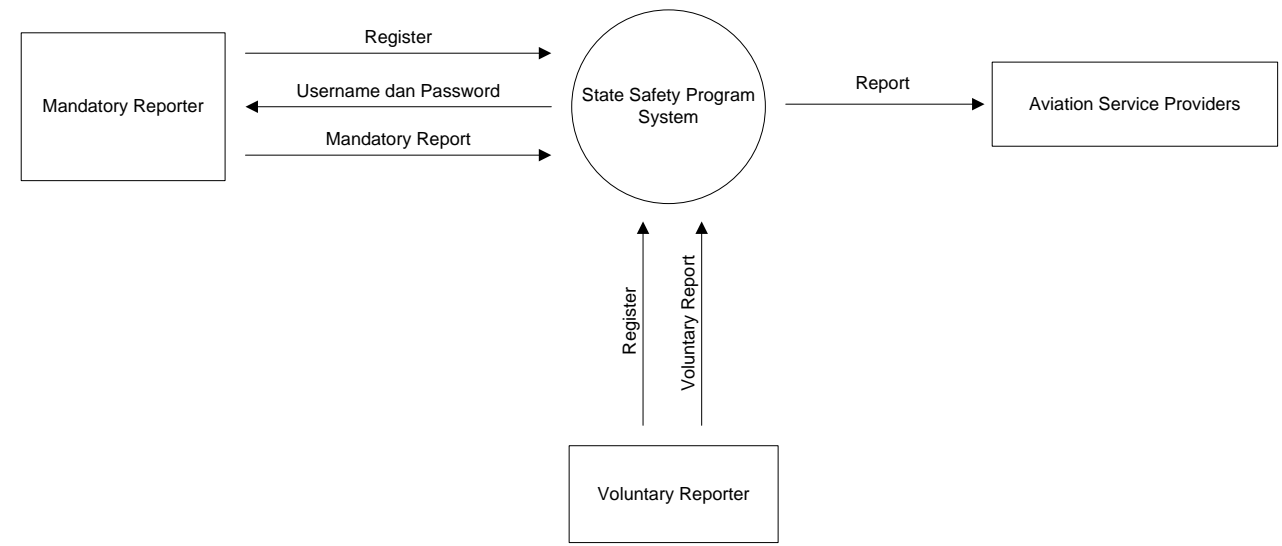

Gambar 2. Diagram Konteks Sistem SSP

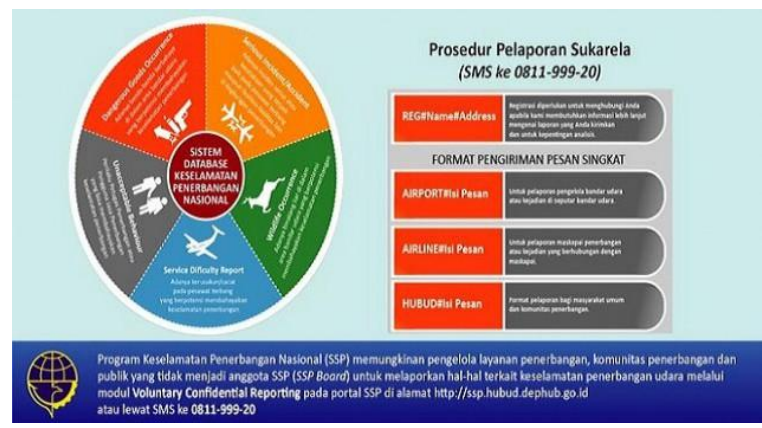

Gambar 3. Prosedur Pelaporan Sukarela (Voluntary Confidential Report)

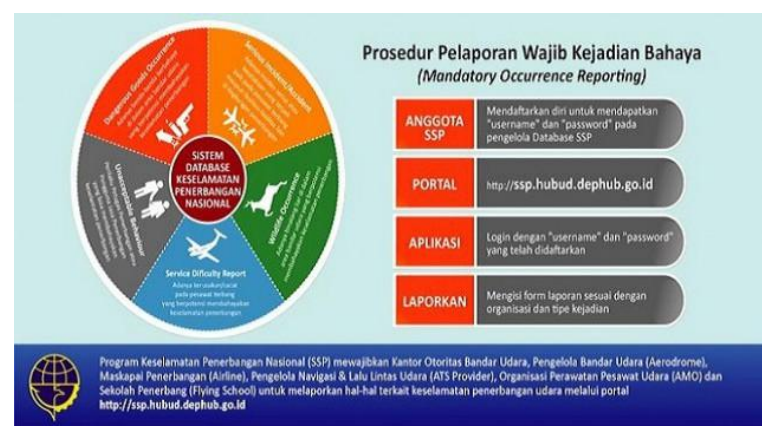

Gambar 4. Prosedur Mandatory Occurrence Reporting (Pelaporan Wajib Kejadian Bahaya)

Sumber : http://ssp.hubud.dephub.go.id/id/

Berdasarkan uraian di atas, Industri Penerbangan Global telah merancang sistem penanganan Layanan Keluhan secara terintegrasi sampai kepada sistem audit danpelaporannya, sehingga kondisi kinerja Industri Penerbangan dapat dijaga untuk memenuhi visi dan misi Industri Penerbangan Sipil yaitu utamakan keselamatan.Berdasarkan seluruh uraian tersebut di atas, dapat diketahui bahwa :

1. Sudah ada sistem manajemen penyampaian keluhan pada industri penerbangan di Indonesia dengan berbasis internet dengan alamat situs : http://ssp.hubbud.dephub.go.id atau lewat Short Message Service (SMS)ke 0811999920, hal ini sesuai dengan pelaksanan kewajiban anggota ICAO untuk melaksanakan SSP (State Safety Program) 
yang merupakan sistem manajemen keselamatan penerbangan nasional dan sebagai salah satu upaya untuk mengelola laporan dan hasil pengawasan oleh Direktorat Jenderal Perhubungan Udara dan Kantor Program Keselamatan Penerbangan Nasional terhadap pelaksanaan keselamatan penerbangan yang dilaksanakan oleh Industri Penerbangan di Indonesia.

2. Sistem manajemen keselamatan penerbangan nasional ini sebagai salah satu upaya untuk mengelola laporan input dari masyarakat untuk meningkatkan tingkat keselamatan penerbangan di Indonesia.

3. Kementerian Perhubungan dalam hal ini Direktorat Jenderal Perhubungan Udara telah membentuk Program Keselamatan Penerbangan Nasional atau State Safety Programe (SSP) yang memiliki fungsi untuk mengidentifikasi dan menangani setiap permasalahan yang mucul dalam dunia Penerbangan nasional. Program Keselamatan Penerbangan Nasional secara rinci dijelasakan dalam KM No 8 Tahun 2010 tentang Program Keselamatan Penerbangan Nasional.

\section{Metodologi Penelitian}

\subsection{Identifikasi Masalah (Problem Identification)}

Keselamatan Penerbangan sebagai visi dan misi yang utama dari Industri Penerbangan Global dapat dimulai dari seluruh aspek operasional sistem yang dilaksanakan, salah satunya adalah bentuk layanan pesan. Sesuai dengan studi literatur, Layanan Pesan/Keluhan yang Ergonomi adalah suatu pendekatan ergonomi berbasis padasistem layanan standar yang disediakan oleh penyedia jasa angkutan udara (airline) yang akan digunakan penumpang airline dalam menyampaikan pesan/keluhan.

\subsection{Pengumpulan Data}

Untuk melakukan studi ini diperlukan data-data terkait dengan layanan informasi pada penerbangan di Indonesia antara lain sebangai berikut :

1. Informasi tentang Pelaksanaan State Safety Programme (SSP)

2. Informasi Layanan Pesan dari Airline/Maskapai..

3. Data keluhan pada YLKI tentang keluhan penumpang untuk Airline.

Data / Informasi tentang Pelaksanaan State Safety Programme (SSP) dapat diakses melalui http://ssp.hubud.dephub.go.id/id/, yang dikelola oleh Direktorat Jenderal Perhubungan Udara, Kementerian Perhubungan Republik Indonesia, sehingga informasi yang dikeluarkan secara resmi oleh regulator dalam hal ini wakil dari pemerintah RI. Data / Informasi layanan dari airline dapat dikutip dari website resmi tiap maskapai/airline, biasanya akan berupa nomor telpon / call center yang dapat diakses 24 jam. Sedangkan untuk informasi dari YLKI dapat diakses melalui media pers baik yang online maupun yang cetak, serta dapat diakses dari situs resmi YLKI yaitu https://ylki.or.id/.

\section{Hasil dan Pembahasan}

Undang-Undang Nomor 1 tahun 2009 tentang Penerbangan dalam Pasal 1, Butir 48 menyatakan bahwa "Keselamatan Penerbangan adalah suatu keadaan terpenuhinya persyaratan keselamatan dalam pemanfaatan wilayah udara, pesawat udara, fasilitas umum lainnya". Untuk penyedia jasa penerbangan di Indonesia bahwa tingkat keselamatan penerbangan dapat dicapai dengan berfungsinya semua unsure terkait antara satu dengan lainnya terhadap penyedia jasa penerbangan.

Mempertimbangkan kemajuan dan ketangguhan teknologi tinggi dalam penerbangan, analisa kecenderungan (trend analysis) atas kecelakaan penerbangan dan penyedia jasa penerbangan, menyimpulkan sebagian besar dari kecelakaan yang terjadi diakibatkan oleh kesalahan manusia (human error). Dari hasil penelitian yang sudah dilakukan, selain faktor 
teknis operasional dan cuaca, penyebab utama kecelakaan diakibatkan ketidakdisiplinan atau kurang terpenuhinya kompetensi personel penerbangan dan organisasi. Penggantian personel penerbangan tidak akan mencegah kecelakaan melainkan yang paling penting dilakukan untuk mencegah kecelakaan adalah mengidentifikasi, memahami serta mengendalikan faktorfaktor inti dari penyebab kecelakaan-kecelakaan yang terjadi sebelumnya.

Pengelolaan keselamatan yang ergonomi memerlukan adanya pemahaman yang sama tentang tanggung jawab dan kontribusi antara pemerintah dan penyedia jasa penerbangan serta seluruh masyarakat. Pengelolaan keselamatan dapat dianggap sebagai proses manajemen yang harus dilaksanakan pada tingkat yang sama dan bersamaan dengan pengelolaan proses-proses lainnya pada tingkat pimpinan tertinggi. Karena pengelolaan keselamatan adalah salah satu dari proses manajemen, setiap bagian organisasi, khususnya pada tingkat pimpinan tertinggi, harus ada penanggung jawab keselamatan. Keselamatan menjadi bagian yang melekat dari setiap prosedur, produk, kebijakan dan teknologi yang bersangkutan dengan Pemerintah dan masing-masing penyedia jasa penerbangan.Permasalahan umum sistem State Safety Programme (SSP) yang dikelola oleh Dirjen Perhubungan Udara dan Fasilitas Layanan Pesan di Airline tidak berjalan optimal dikarenakan beberapa faktor:

a. Kurangnya sosialisasi program State Safety Programme (SSP) ini terutama untuk voluntary reporter, sehingga masyarakat umum tidak mengetahui dan tidak dapat berpatisipasi terhadap keselamatan penerbangan.

b. Pengguna yang diwajibkan melakukan pendaftaran (registrasi) terlebih dahulu sebelum dapat melaporkan kejadian, sehingga cukup merepotkan, padahal setiap nomor telepon sudah terigestrasi semua saat ini.

c. Ketakutan pengguna atas sangsi hukum dari laporan yang diberikan karena walaupun secara jelas dituangkan dalam Undang-undang No. 1 tahun 2009 bahwa pelapor dilindungi, akan tetapi peraturan pelindungnya belum disahkan.

Kondisi sistem layanan yang seperti ini tidak ergonomi karena pengguna merasa tidak nyaman. Permasalahan yang timbul akibat kurangnya sosialisasi dan rumitnya proses registrasi dapat diatasi jika sistem yang berjalan telah diintegrasikan menjadi satu antara sistem-sistem yang terlibat dalam transportasi udara seperti sistem penjualan tiket, sistem informasi kepegawaian dan sistem-sistem lain yang memuat seluruh pengguna SSP ini. Sebagai contoh sistem penjualan tiket (airline) yang memuat data pengguna sebagai stakeholder terbawah dari Aviation Service Provider. Apabila data dari penumpang (yang tervalidasi saat proses check-in) dapat dibaca oleh SSP, sistem yang berjalan dapat mebroadcast menggunakan Short Message Service (SMS) informasi adanya program SSP kepada penumpang sekaligus meregistrasikan mereka sehingga pengguna tinggal mereplaypesan tersebut sebagai bentuk laporan (reporting).Bentuk integrasi data ditunjukkan pada gambar 5 berikut:

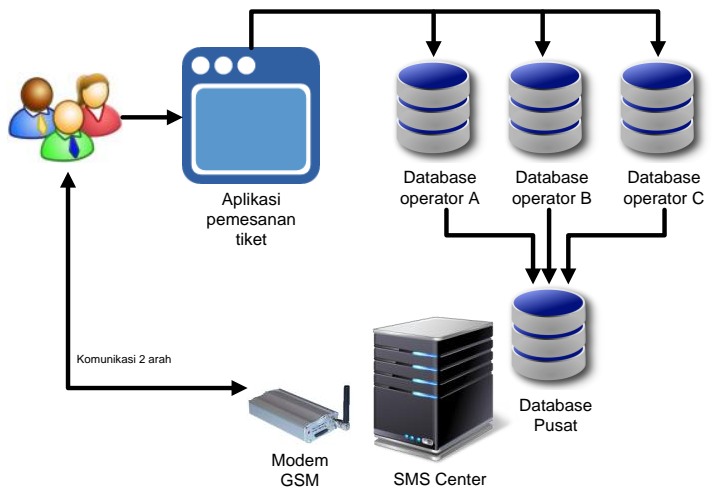

Gambar 5. Integrasi System SSP dengan Data Operator Airline 
Jika proses pada gambar 6 di atas dapat dilakukan, maka diagram konteks ditunjukkan pada gambar 6 sebagai berikut:

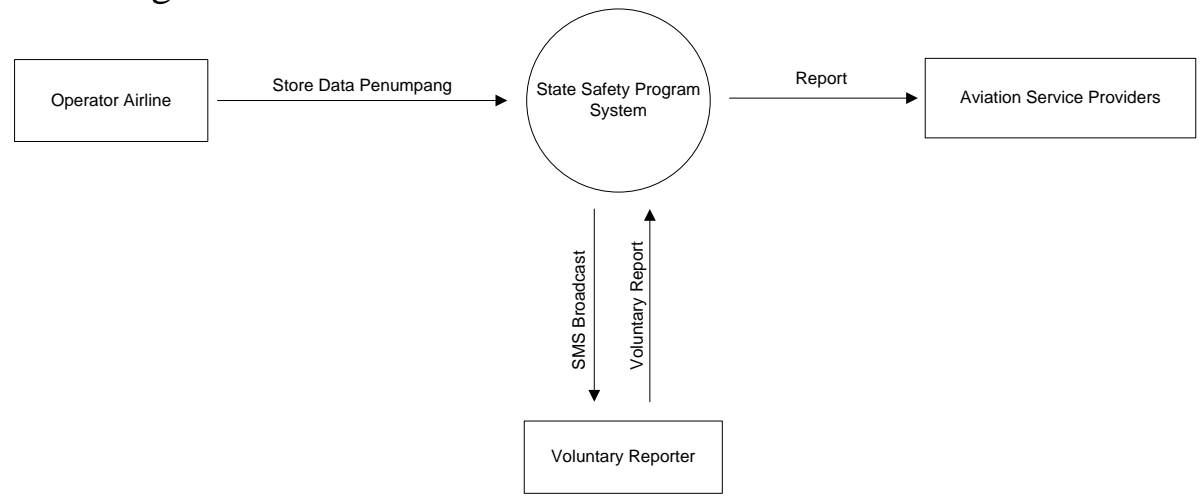

Gambar 6. Diagram konteks sistem pelaporan sukarela yang ditawarkan

Untuk sistem Pelaporan wajib, program SSP ini dapat bekerjasama dengan badan/ pihak ketiga (third party) seperti teknisi perawatan dan sebagainya yang menyimpan data kepegawaian khususnya pegawai yang berkewajiban melaporkan kejadian insiden pesawat terbang. Proses integrasi ini diilustrasikan pada Gambar 7.

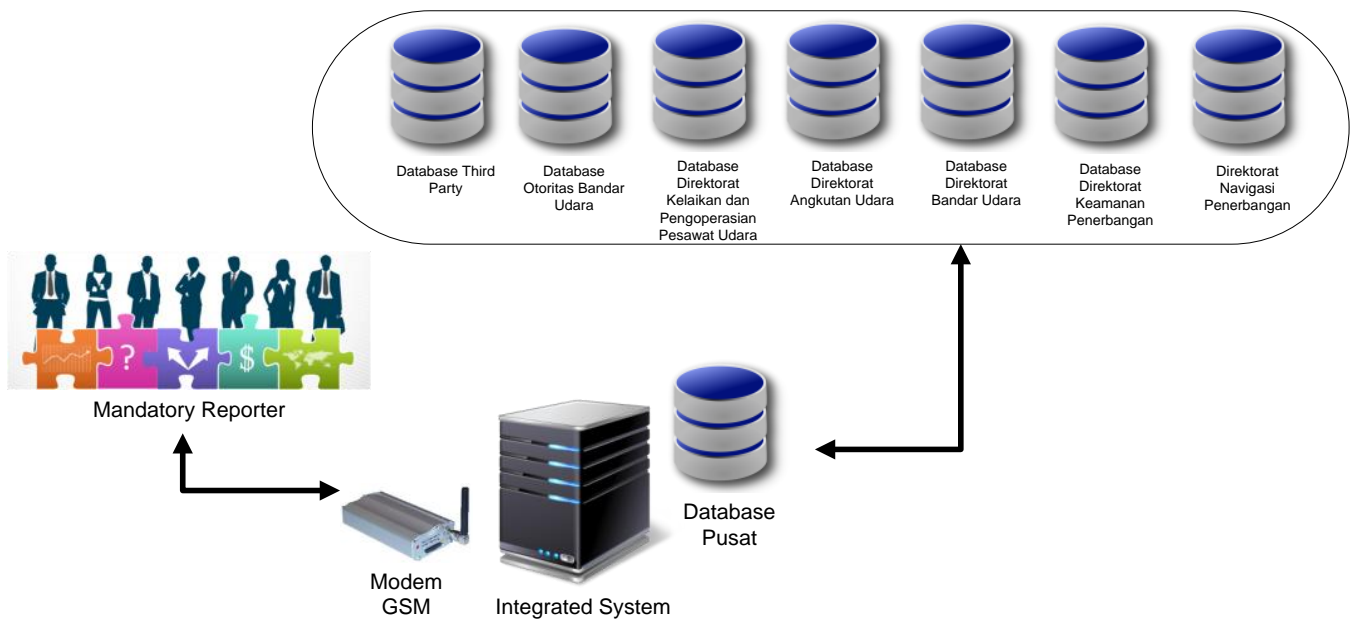

Gambar 7. Integrasi dengan berbagai sistem

Proses integrasi antara sistem SSP dan sistem eksternal tidak memaksa sistem-sistem tersebut dikembangkan pada platform yang sama. Sistem-sistem tersebut tetap dikembangkan dan berjalan secara mandiri dan terpisah-pisah (heterogeneous). Berdasarkan semua uraian di atas, maka secara ergonomi layanan informasi/pesan yang diaplikasikan sangat memudahkan pengguna dalam hal ini adalah penumpang airline dalam menyampaikan keluhan.

Berkaitan dengan pengembangan sistem informasi yang dapat dilakukan oleh airline, yang langsung berhubungan dengan stakeholder penumpang membutuhkan respon yang lebih cepat dari masing-masing operator airline. Untuk mempercepat respon yang ada maka sistem informasi yang masuk dari penumpang seharusnya langsung dapat dipisahkan menjadi pesan layanan dan pesan keselamatan. Untuk pesan layanan dapat disampaikan diteruskan ke unit yang bertanggung-jawab sesuai dengan isi keluhan untuk segera di respon, sedangkan pesan keselamatan dapat disampaikan ke pihak manajemen untuk segera direspon serta dapat dijadikan laporan ke State Safety Programe (SSP). Proses pemisahan pesan layanan dan pesan keselamatan yang dapat dikembangkan oleh airline dapat digambarkan dengan diagram konteks. 
Diagram konteks adalah diagram tingkat atas yang hanya menggambarkan sistem secara garis besar. Merupakan diagram garis besar yang paling tidak detail dari sebuah sistem yang menggambarkan kesatuan-kesatuan luar sistem. Dalam diagram ini digambarkan Admin sebagai pengelola keseluruhan sistem klasifikasi ini, Seperti login, input data dan laporan. Sedangkan User hanya untuk mengirimkan pesan keluhan melalui Short Message Service (SMS). Diagram Konteks ini dapat dilihat pada Gambar 8 dibawah ini :

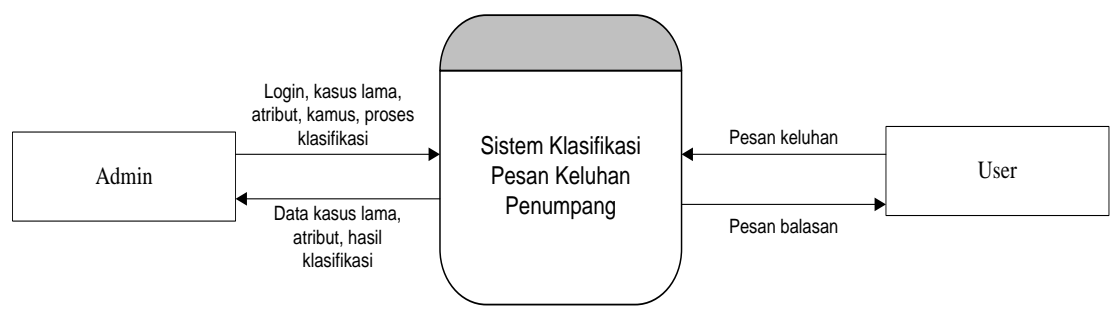

Gambar 8. Diagram Konteks Klasifikasi Pesan

DAD Level 0 Sistem Klasifikasi Pesan Keluhan Penumpang Airline

Diagram ini akan memberikan gambaran secara keseluruhan mengenai sistem, baik berupa proses-proses yang berlangsung, aliran data, penyimpanan data. Pada level ini, ada 2 proses dalam Gambar 9 yaitu proses halaman admin dan proses halaman user. Alur data ini dimulai dengan admin melakukan proses login dihalaman admin, setelah proses login admin mengelola data seperti kasus lama, atribut, kamus, dan proses klasifikasi. Sedangkan untuk entitas User hanya dapat mengirimkan pesan keluhan melalui Short Message Service (SMS). Berikut ini adalah Gambar 9. DAD level 0 Sistem Klasifikasi Pesan Keluhan Penumpang Airline.

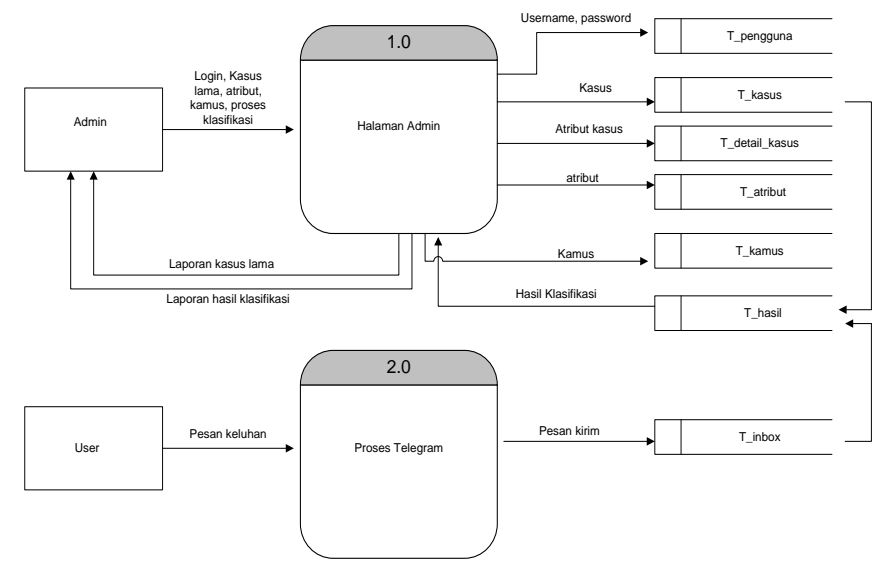

Gambar 9. DAD Level 0 Sistem Klasifikasi Pesan Keluhan Penumpang Airline

\section{DAD Level 1 Proses Admin}

DAD level 1 proses admin merupakan penjabaran bagian admin terhadap sistem yang ada. Admindapat mengelola data yang ada didalam sistem dan data yang mendukung proses sistem user. Admin dapat melakukan proses input data hingga memberikan laporan kepada user. Proses input data yang dilakukan oleh admin seperti menambah data kamus, detail kasus, atribut, dan kamus. Admin juga dapat melakukan proses ubah, hapus pada kasus yang lama dan proses klasifikasi pesan yang dikirimkan user kepada sistem. Selain itu admin juga dapat memberikan hasil klasifikasi dari sebuah pesan yang dikirimkan oleh user. Berikut ini tampilan proses admin untuk lebih jelasnya dapat dilihat pada Gambar 10. 


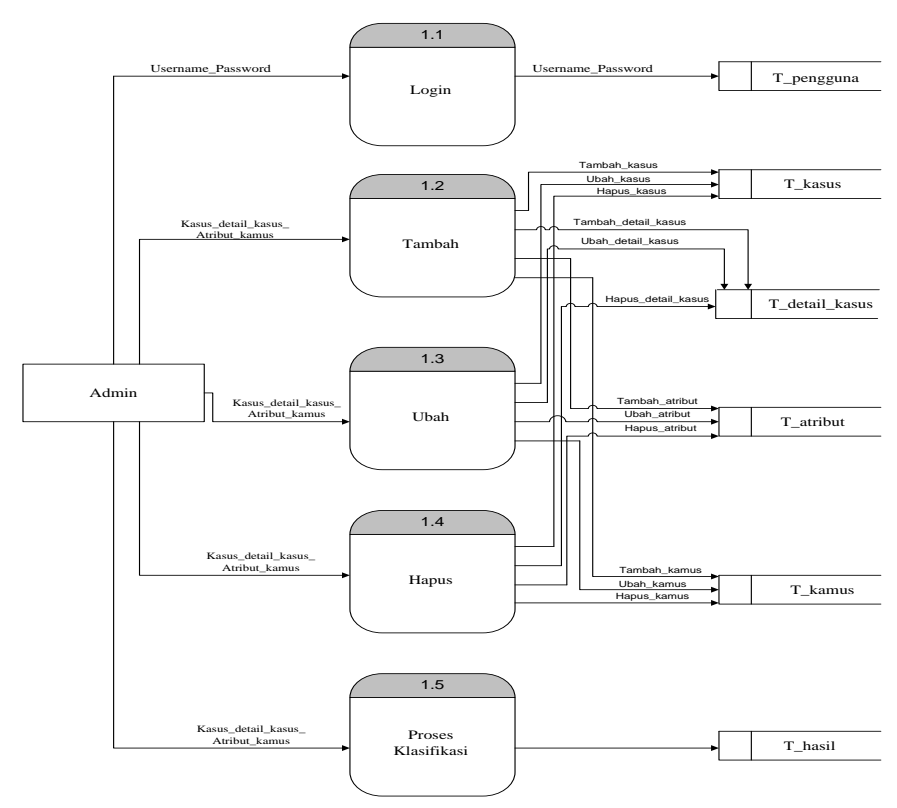

Gambar 10. DAD level 1 proses admin

\section{DAD Level 1 Proses User}

Pada Dad Level 1 proses User merupakan penjabaran bagian pengguna atau User. Pada proses ini, User sebagai pengguna dalam sistem ini men-input-kan pesan menggunakan Telegram yang nantinya akan dikirimkan kepada admin yang diolah sebagai pesan keluhan penumpang. Umpan balik dari admin yang diterima user adalah pesan balasan yang diterima pengguna bahwa pesan sudah terkirim dan diterima admin. Berikut ini adalah Gambar 11 DAD Level 1 Proses User.

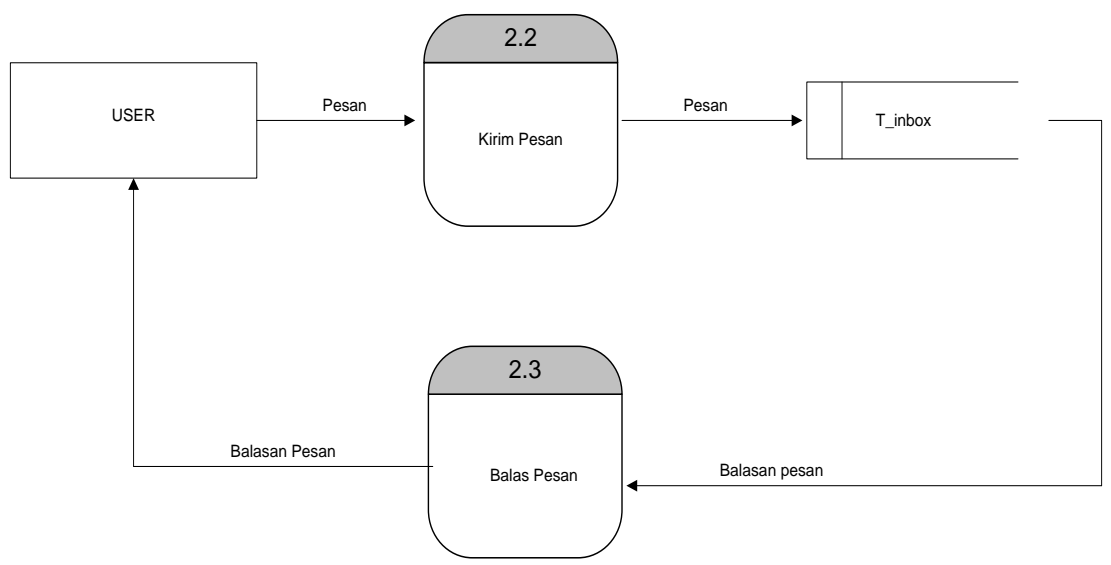

Gambar 11. DAD Level 1 Proses User

Berdasarkan pengembangan sistem informasi yang dapat dilakukan oleh airline, maka pihak airline dalam hal ini yang bertugas customer service menjadi lebih mudah dan respon yang disampaikan ke user dalam hal ini penumpang menjadi lebih cepat. Kenyamanan sistem pelayanan yang ergonomi seperti ini sangat diharapkan oleh semua pihak, baik konsumen internal (seluruh personel di airline) maupun eksternal (penumpang airline), karena beban kerja personil juga ringan dan respon yang diharapkan oleh user/penumpang menjadi cepat. Jika sistem informasi layanan pesan sesuai dengan kaidah-kaidah dalam ergonomi maka tingkat pelayanan dan keselamatan penerbangan tiap airline dapat dipertahankan dan ditingkatkan secara signifikan. 


\section{Kesimpulan}

a. Sudah ada sistem layanan keluhan di masing-masing airline, baik yang online maupun yang offline. Hal ini sesuai dengan PM 185 Tahun 2015, Bab VII (Penanganan Keluhan Penumpang) Pasal 58 ayat (1) Badan usaha angkutan udara wajib mempunyai manajemen penanganan keluhan penumpang. (2) Penanganan keluhan penumpang sebagaimana dimaksud, dapat dilakukan melalui media: a. secara langsung atau lisan; b. surat tertulis; c. SMS; d. Telepon; e. Kotak Saran; f. E-mail; dan g. sarana lainnya.

b. Pengembangan sistem informasi layanan pesan/keluhan perlu dilakukan oleh seluruh stakeholder Industri Penerbangan untuk dapat mengintegrasikan sistem informasi keselamatan penerbangan sesuai dengan rekomendasi ICAO annex 13, Aircraft accidents dan Incident investigation. Negara harus menetapkan Sistem Pelaporan Sukarela atau Voluntary Confidential Report diluar sistem pelaporan wajib atau Mandatory Occurrence Reporting.

c. Pengembangan Sistem Layanan Pesan/Keluhan di Airline yang dapat dilakukan dengan memisahkan antara pesan layanan dan pesan keselamatan sehingga dapat meningkatkan respon keluhan dengan cepat serta budaya keselamatan penerbangan dapat ditingkatkan.

\section{Daftar Pustaka}

[1] Tristiaratri, A., Brata, A., \& Fanani, L. (2017). Perbandingan User Interface Aplikasi Mobile Pemesanan Tiket Pesawat Online dengan Design Thinking. Jurnal Pengembangan Teknologi Informasi Dan Ilmu Komputer, 2(6), 2113-2120. Diambil dari http://j-ptiik.ub.ac.id/index.php/j-ptiik/article/view/1509

[2] Agoes, A., \& Dewi, S. W. R. (2018). Motivasi Konsumen Dalam Menggunakan Layanan Tiketing Di Agen Perjalanan Konvensional. Jurnal Sains Terapan Pariwisata, $3(2), 159-171$.

[3] Rudianto, A., (2017). Kajian Ergonomi Pada Visual Display Penunjuk Informasi Pelabuhan di Kawasan Kuala Enok. Jurnal BAPPEDA Selodang Mayang, 3(1), 24427845, 30-34.

[4] Mardoko, A. (2017). Tingkat Kepuasan Penumpang Terhadap Layanan Maskapai Penerbangan PT. Lion Air Rute Mamuju - Jakarta. Warta Ardhia, 41(1), 19. doi:10.25104/wa.v41i1.141.19-28

[5] Peraturan Menteri Perhubungan Republik Indonesia, Nomor PM 185 Tahun 2015, Tentang Standar Pelayanan Penumpang Kelas Ekonomi Angkutan Udara Niaga Berjadwal Dalam Negeri.

[6] Keputusan Menteri Perhubungan Nomor : KM 8 tahun 2010 tentang Program Keselamatan Penerbangan Nasional, dan Peraturan Menteri Perhubungan Nomor KM 20 tahun 2009 tentang Sistem Manajemen Keselamatan (Safety Management System).

[7] Aircraft accident and incident investigation: International standards and recommended practices: Annex 13 to the Convention on International Civil Aviation. (2010). Montre'al: International Civil Aviation Organization.

[8] Undang-Undang Nomor 1 tahun 2009 tentang Penerbangan.

[9] Silvia, M., (2014). Pengaruh Service Quality Terhadap Customer Satisfaction dan Behavioral Intention pada Industri Penerbangan Low Cost Carriers Rute Domestik di Surabaya. Jurnal Ilmiah Mahasiswa Universitas Surabaya, 3(2).

[10] Muchtiar, Y., Bidiawati, A., \& Putra, D.T., (2017). Perancangan Desain Blog Promosi Dengan Mempertimbangkan Aspek Display Ergonomi. Prosiding SENIATI, 3(2), C55.1-5. 
[11] Poerwanto, E., \& Mauidzoh, U. (2016). Analisis Kecelakaan Penerbangan Di Indonesia Untuk Peningkatan Keselamatan Penerbangan. Angkasa: Jurnal Ilmiah Bidang Teknologi, 8(2), 9-26.

[12] Poerwanto, E., \& Gunawan, G. (2015). Analisis Beban Kerja Mental Pekerja Bagian Ground H Andling Bandara Adisutjipto untuk Mendukung Keselamatan Penerbangan. Angkasa: Jurnal Ilmiah Bidang Teknologi, 7(2), 115-126. 